ROCZNIKI TEOLOGICZNE

Tom LXVI, zeszyt 2 - 2019

DOI: http://dx.doi.org/10.18290/rt.2019.66.2-4

ANTON ADAM

\title{
CHARISMS IN THE SERVICE OF THE UNIVERSAL CHURCH
}

\begin{abstract}
A b s t r a c t. The Church, as a community, is accompanied by the constant presence of the Holy Spirit, whose Son of God has not only promised, but has sent in the day of Pentecost. It is not the purpose of the Holy Spirit; The Church is to be revived by the Holy Spirit, which sanctifies it in individual believers. Jesus' requirement of holiness is the expression of the attitude of a just man who gives him the gift of grace - charisms, he uses for the benefit of the development of his own personal perfection, and also every person use charisms to serve the Church Community. As an individual is not the saint of egoism but a community servant. If he is to persevere in this truth, he must constantly nourish the consciousness of God's presence and work for the benefit of the community.
\end{abstract}

Key words: Church; Charisms; Holy Spirit; Grace; Authenticity.

The Church, as a community, is accompanied by the constant presence of the Holy Spirit, whose Son of God has not only promised, but has sent in the day of Pentecost. "But very truly I tell you, it is for your good that I am going away. Unless I go away, the Advocate will not come to you; but if I go, I will send him to you. [...] But when he, the Spirit of truth, comes, he will guide you into all the truth. He will not speak on his own; he will speak only what he hears, and he will tell you what is yet to come" (Jn 16:7.13). Second Vatican Ecomunical Council emphasized the admirable work of the Holy Spirit, which sanctifies the people of God, guides him in the path of salvation, ornaments his virtues, and enriches him with special gifts for his building. Ecclesiologically, the Church must be understood as the gift of the

Prof. ThDr. ANTON ADAM, PhD - Comenius University in Bratislava, Faculty of Roman Catholic Theology of Cyril and Methodius; Kňazský seminár sv. Františka Xaverského, 2897401 Banská Bystrica - Badín; address for correspondence: e-mail: a.adam@stonline.sk 
Father, and as the mystical body of Christ. This body is revived by the Holy Spirit, who gives the Church its services, offices and charisms. The Holy Spirit brings the Church to the end when he has a share in the trinity of God's life. The gifts of the Holy Spirit are present in the life of the believer and sanctify his actions so that he is faithful to all his deeds, he is faithful to his baptismal vocation. Because of the blessedness of baptism he became a god's child and is invited to persevere in good order and effects until the end of earthly life. Pope John Paul II., in the encyclical about the Holy Spirit in the life of the Church and the world of Dominum et Vivificantem, refers to the dogmatic constitution of Lumen gentium: The Spirit dwells in the Church and hearts of the faithful as in the temple (cf. 1 Cor 3:16; 6:19) prays and gives testimony that we are received for the children of God (cf. Gal 4:6, Rom 8:15-16 and 26). The Church - which brings to all truth (Jn 16:13) and unites in communion (in communione) and service-makes and guides through various hierarchical and charismatic gifts and embellishes it with its fruits (cf. Eph 4:11-12; 1 Cor. 12:4; 5:22). "The Holy Spirit rejuvenates the Church in the power of the Gospel, and the Spirit continually renews her, and leads to perfect unity with her groom." 1 The patristic and theological tradition points to the inner union of the Holy Spirit and the Church, which, by analogy, sometimes represents the union of the soul and the body. ${ }^{2}$ John Paul II considers the truth of the Pentecost like defining the beginning of the Church's action. At the same time, the action of the Holy Spirit is a permanent testimony of the Church's presence and activity to this day; the action of the Spirit, who sanctifies everything, is the guarantee of the strength and faithfulness of Christ's community. The history of the Church for centuries points to the truth of Jesus' statement, which is echoed in the promise he gives to Peter: "And I also say to you that you are Peter, and on this rock I will build my church, and the gates of Hades will not overpower it" (Mt 16:18). The Second Vatican Council has also taken up this content in the constitutions Lumen gentium and Gaudium et spes, in which

\footnotetext{
${ }^{1}$ Second Vatican Ecumenical Council, Constitution Lumen Gentium, 4. Cf. John PAUL II, Encyclical Dominum et Vivificantem, 25.

${ }^{2}$ Cf. SAint Irene, Adversus haereses, III, 24,1, SC 211, p. 470-474; ST. Augustine, Sermo 267, 4.4: PL 38, 123; Sermo 268, 2, PL 38, 1232; In Johannis Gospel Tractatus, XXVI, 13; XXVII, 6, CCL 36, 266, 272n.; SAINT GRegORY the Great, In Psalmos poenitentiales expositio, Psalm. V, 1, PL 79, 602; Didymus DE Blind, De Trinity, II, I, PG 39, 449n.; St. Athanasius, Oratio III conra arianos, 22, 23, 24: PG 26, 368n.; 372n.; ST. John ChrySOstom, In the epistle of Ephesians, Homil IX, 3, PG 62. 72n.
} 
it presents both the faithful and pastoral truths explaining the mission and importance of the Church in the history of salvation and the history of mankind. That is why John Paul II. about the Concil said: "We know that it has been extensively ecclesiological": a council focused on the theme of the Church. Along with the teaching of this Council is fundamentally pneumatological: is penetrated the truth about the Holy Spirit as the soul of the Church. We can say that The Second Vatican Council, in its rich doctrine, contains everything that means "the Holy Spirit speaks to the churches" (cf. Rev. 2:29; 3:6; 13:22) at the present time of the salvation history. The Council, by being guided by the Spirit of Truth and testifying with it, became a special confirmation of the presence of the Holy Spirit - the Teacher. In a sense, the Holy Spirit reappeared in our difficult time. ${ }^{3}$ John Chrysostom write: "What gifts that work for our salvation are not given freely by the Holy Spirit? Through Him we are freed from slavery and called to liberty; we are led to adoption as children and, one might say, formed anew, after having laid down the heavy and hateful burden of our sins. Through the Holy Spirit we see assemblies of priests and we possess ranks of doctors; from this source spring forth gifts of revelation, healing graces, and all of the other charisms that adorn the Church of God." 4 The mission of the Council is to answer the question Ecclesia, quid dicis de teipsa, but at the same time respond to the whole spectrum of questions posed by the present humanity, including the Church. The council is supposed to be ecclesiological, but not in the narrow and defined sense of the word, but in the broad and open to all the needs of the world. In the pastoral constitution, we read: "For theirs is a community composed of men. United in Christ, they are led by the Holy Spirit in their journey to the Kingdom of their Father and they have welcomed the news of salvation which is meant for every man. That is why this community realizes that it is truly linked with mankind and its history by the deepest of bonds." 5 The Church is aware of its mission in this world. $\mathrm{He}$ knows that only the God he serves corresponds to the desires of the human heart, which will never be satisfied in the fullness of the earthly good. Unique way "The Spirit of God [...] with exorbitant providence directs the course of time and restores the face of the earth."

\footnotetext{
${ }^{3}$ John PAUL II, Encyclical Dominum et Vivificantem, 26.

${ }^{4}$ John Chrysostom, Homilia de Pentecoste, II, 1: PG 50, 464.

${ }^{5}$ Second Vatican Ecumenical Council, Constitution Gaudium et spes, 1.

${ }^{6}$ Second Vatican Ecumenical Council, Constitution Gaudium et spes, 26.
} 
all times, in all circumstances of human life, to announce the joyful message of Jesus Christ, which came to every person. Catechism of the Catholic Church teaches: "So that she can fulfill her mission, the Holy Spirit bestows upon [the Church] varied hierarchic and charismatic gifts, and in this way directs her."7 The Congregation for the Doctrine of the Faith in the Letter of Bishops of the Catholic Church on the Relationship between the Hierarchical and Charismatic Gifts for Life and the Mission of the Church of the Iuvenescit Ecclesia highlights the importance of charisms: "Thanks to the Church's life itself, to the numerous Magisterial interventions, and to theological research, happily the awareness has grown of the multiform action of the Holy Spirit in the Church, thus arousing a particular attentiveness to the charismatic gifts by which at all times the People of God are enriched in order to carry out their mission." 8 About charisms the Church teaches as extraordinary gifts that are the grace of the Holy Spirit and are directly or indirectly beneficial to the Church, and are also focused on building the Church or on the good of the people and the needs of the world. ${ }^{9}$ Every gift comes from the Father, through the Son, in the Holy Spirit. The gift of the Spirit in the Church is bound to the mission of the Son, accomplished definitively in his Paschal Mystery. Jesus Himself connects the fulfilment of his mission to the sending of the Spirit upon the community of believers. "But the Counselor, the Holy Spirit, whom the Father will send in my name, will teach you all things and remind you of everything I have told you" (Jn 14:26). The Congregation for the Doctrine of the Faith emphasizes that "through this, the Holy Spirit can in no way inaugurate an economy other than that of the divine incarnate Logos, crucified and risen. In truth, the whole sacramental economy of the Church is the pneumatological realization of the Incarnation: the Holy Spirit, therefore, comes to be considered by Tradition as the soul of the Church which is the Body of Christ. The action of God in history always implies the relationship between the Son and the Holy Spirit, who, in Irenaeus of Lyon's evocative words, are called „the two hands of the Father." 10 The Congregation for the Doctrine of the Faith Iuvenescit Ecclesia clearly declares the interrelationship between hierarchical and charismatic gifts: "The bond in origin between the hierarchal gifts, con-

\footnotetext{
${ }^{7}$ Catechism of the Catholic Church, 768.

${ }^{8}$ Congregation for the Doctrine of THE FAith, Iuvenescit Ecclesia, 1.

${ }^{9}$ Catechism of the Catholic Church, 779.

${ }^{10}$ Congregation for the Doctrine of the Faith, Iuvenescit Ecclesia, 11.
} 
ferred with the sacramental grace of Orders, and the charismatic gifts, freely distributed by the Holy Spirit, has its deepest roots, therefore, in the relationship between the divine incarnate Logos and the Holy Spirit, who is always the Spirit of the Father and of the Son. Precisely to avoid equivocal theological visions that would posit a «Church of the Spirit», distinct and separate from the hierarchical-institutional Church, it must be repeated that the two divine missions mutually imply each other in every gift bestowed freely upon the Church. In reality, the mission of Jesus Christ already implies within itself the action of the Spirit."11 Every person is participating in God's gifts; because the Holy Spirit acts undoubtedly in the soul of man, it is important to be attentive and spiritually sensitive to the motives of God's love, so that we also accept the received gift for the benefit of personal life, but also the general good of the Church. During the World Congress of Church Movements, which took place in the Vatican in 1998 (27th - 29th of May), these words were said by John Paul II: "Today, I would like to cry out to all of you gathered here in St Peter's Square and to all Christians: Open yourselves docilely to the gifts of the Spirit! Accept gratefully and obediently the charisms which the Spirit never ceases to bestow on us! Do not forget that every charism is given for the common good, that is, for the benefit of the whole Church." 12 The inner good of man represents the state of God's love, which we receive as a free given gift. It is the status of a rightful person who, in conjunction with the gifts of the Holy Spirit, sanctifies and becomes a participant in God's gifts. Charitology of the Catholic Church defines grace also in the following way: "Grace is first and foremost the gift of the Spirit who justifies and sanctifies us. But grace also includes the gifts that the Spirit grants us to associate us with his work, to enable us to collaborate in the salvation of others and in the growth of the Body of Christ, the Church. There are sacramental graces, gifts proper to the different sacraments. There are furthermore special graces, also called charisms after the Greek term used by St. Paul and meaning «favor,» «gratuitous gift,» «benefit.» Whatever their character - sometimes it is extraordinary, such as the gift of miracles or of tongues - charisms are oriented toward sanctifying grace and are intended for the common good of the Church. They are at the service of charity which

${ }^{11}$ Congregation for the Doctrine of the Faith, Iuvenescit Ecclesia, 11.

12 John PAUL II, "Interpretation of the Holy Witness 30 May 1998", in: Papal Leaves and Vatican Documents, vol. 14, World Congress of the Church Movements. Vatican 27.-29 May 1998 (Trnava: St. Vojtech's Association, 1998), cap. 5, p. 55. 
builds up the Church." 13 John Paul II in the apostolic exhortation Christifideles laici of the vocation and mission of laymen in the Church and in the world, the presence of the charisma explains in the following way: "The Holy Spirit, while bestowing diverse ministries in Church communion, enriches it still further with particular gifts or promptings of grace, called charisms. These can take a great variety of forms, both as a manifestation of the absolute freedom of the Spirit who abundantly supplies them, and as a response to the varied needs of the Church in history. The description and the classification given to these gifts in the New Testament are an indication of their rich variety." manifestation of the Spirit for the common good. To one is given through the Spirit the utterance of wisdom, and to another the utterance of knowledge according to the same Spirit, to another faith by the same Spirit, to another gifts of healing by the one Spirit, to another the working of miracles, to another prophecy, to another the ability to distinguish between spirits, to another various kinds of tongues, to another the interpretation of tongues." (1 Cor 12:7-10; cf. 1 Cor 12:4-6,28- 31; Rom 12:6-8; 1 Pt 4:10-11).

\section{CHARISMS IN ECCLESIOLOGICAL CONTEXTS}

Each individual Christian contributes with his charisms and services to the building of the Church. It is the permanent mission of the Church and not just the initial enthusiasm (cf. 1 Thess 5:19). God's people as a whole participate in Christ's prophecy, royal and priestly ministry of salvation. Because the Church, as the place where God's presence is, is filled with the Spirit by the Father and the Son, it is also the Christ Spirit, who is the originator of all the various services, offices and free charisms through which the Prophetic, Royal, and Priesthood service of the Church serves. This way "the Catholic Church strives constantly and with due effect to bring all humanity and all its possessions back to its source In Christ, with Him as its head and united in His Spirit." 15 The New Testament texts of the Holy Scriptures point out that there is no contradiction between the various charisms, but they show their harmonious connection and complementarity. Paul describes his

\footnotetext{
13 Catechism of the Catholic Church, 2003.

14 John Paul II, Apostolic Exhortation Christifideles Laici, 24, AAS 81(1989), 434.

15 Second Vatican Ecumenical Council, Dogmatic constitution Lumen Gentium, 13.
} 
apostolic service as "the service of the Spirit" (2 Cor 3:8). He realizes that he has been entrusted with the authority the Lord has given to him (cf. 2 Cor $10: 8 ; 13: 10)$ and which also applies to charism's bearers. Also the apostle Peter gives instructions to charismatics how to use charisms. Both apostles are convinced of divine origin by charisms; despite this truth they do not consider them to be the gifts which would justify denunciation of obedience to the Church hierarchy, or give the right to autonomous service. Pavol is aware of the inconvenience that can arise in the Christian community for the unconditional use of charisms. The Apostle therefore interferes with his authority and sets forth precise rules for the use of the charisma "in the Church" (1 Cor 14:19.28) during the assembly of the community (1 Cor 14:23.26). The dogmatic constitution Lumen Gentium say: "the Holy Spirit sanctifies and leads the people of God and enriches it with virtues, but, «allotting his gifts to everyone according as He wills» (1 Cor 12:11)." ${ }^{16}$ It is good to note what the Church's teaching about the charisms is saying: "Charisms are to be accepted with gratitude by the person who receives them and by all members of the Church as well. They are a wonderfully rich grace for the apostolic vitality and for the holiness of the entire Body of Christ, provided they really are genuine gifts of the Holy Spirit and are used in full conformity with authentic promptings of this same Spirit, that is, in keeping with charity, the true measure of all charisms." to the inner movement, which registers itself as a motive for further action. Therefore, it is in the spot to be aware of the admonition addressed by St. John the Apostle: "Dear friends, do not believe every spirit, but test the spirits to see if they are from God, because many false prophets have gone out into the world. This is how you know the Spirit of God: Every spirit that confesses that Jesus Christ has come in the flesh is from God" (1 Jn 4:1-2). The Christians accept the variety of charisms, with which we can engage in various works and tasks useful for the renewal and further building of the Church as written: "A manifestation of the Spirit is given to each personfor the common good" (1 Cor 12:7). However, there is a certain danger in applying the charisms and realizing the work that results from them. Jesus' invitation is a challenge to float on the sea that we can run the net into deeper waters (cf. Lk 5:4). He invites every man to fill our lives in the service of brothers and sisters-that is, neighbors. If we associate with him, we

\footnotetext{
16 Second Vatican Ecumenical Council, Dogmatic constitution Lumen Gentium, 12.

${ }^{17}$ Catechism of the Catholic Church, 800.
} 
have the courage to put our charisms into service to others. Inspiration of active love let Christ's love for us be (2 Cor 5:14) so that we can honestly confess with the apostle Paul: "For if I preach the gospel, I have no reason to boast, because I am compelled to preach - and woe to me if I do not preach the gospel!" (1 Cor 9:16). Charismatic gifts can not be perceived outside the context of the Church's life. They have a place in it in close relation to hierarchical gifts, as we have pointed out above. The Church has a mission that has been entrusted to him by the Son of God. When we point out the presence and action of the Holy Spirit in the life of the Church, we emphasize not only the trinitarian theological doctrine with emphasis on pneumatology, but we also recall the ecclesial context in the Christocentrism of salvation. This is the expression of the very purpose of Jesus Christ to establish the Church that will fulfill the salvation mission. ${ }^{18}$ The enternal Father's plan "was to raise men to a participation of the divine life." 19 It does do it so by gathering people around your Son Jesus Christ. This gathering is the Church, which is the "birth and the beginning" of the Kingdom of God. ${ }^{20}$ The Holy Spirit "dwelling in those who believe and pervading and ruling over the Church as a whole, who brings about that wonderful communion of the faithful. He brings them into intimate union with Christ, so that $\mathrm{He}$ is the principle of the Church's unity." ${ }^{21}$ Conciliar fathers, who are at the heart of a genuine interest in the good of the Church community in the sense of responsibility for the mission that the Church entrusts to them in their offices, also addressed the faithful: "Extraordinary gifts are not to be sought after, nor are the fruits of apostolic labor to be presumptuously expected from their use; but judgment as to their genuinity and proper use belongs to those who are appointed leaders in the Church, to whose special competence it belongs, not indeed to extinguish the Spirit, but to test all things and hold fast to that which is good" (cf. 1 Thess $5: 12 ; 19-21){ }^{22}$ Frequent external manifestations are specific forms of practicing religious cults. The Congregation for the Doctrine of Faith concludes: "To the value and richness of all the traditional organizations, characterized by particular purposes, as well as the Institutes of Consecrated Life and the Societies of Apostolic Life, are added those more recent realities that can be described as

\footnotetext{
18 Catechism of the Catholic Church, 541.

19 Second Vatican Ecumenical Council, Dogmatic constitution Lumen Gentium, 2.

${ }^{20}$ Second Vatican Ecumenical Council, Dogmatic constitution Lumen Gentium, 5.

${ }^{21}$ Second Vatican Ecumenical Council, Decree Unitatis redintegratio, 2.

${ }^{22}$ Second Vatican Ecumenical Council, Dogmatic constitution Lumen Gentium, 12.
} 
groups of the faithful, ecclesial movements, and new communities. This present document reflects upon these realties." ${ }^{, 23}$ It is clear that here are the movements and communities that originated and were created in the period after the Second Vatican council. We talk about communities who are very dynamic, can be innovative in finding new forms of religious expression and personal survival of faith. However, it is important to be aware of these communities "cannot simply be understood as a voluntary association of persons desiring to pursue a particular social or religious goal." ${ }^{24}$ John Paul II says: "These charisms are given to individual persons, and can even be shared by others in such ways as to continue in time a precious and effective heritage, serving as a source of a particular spiritual affinity among persons" ${ }^{25}$ and it is just friendship in Christ, which is the foundation of the movement. "The passage from the original charism to the movement happens through the mysterious attraction that the founder holds for all those who become involved in his spiritual experience." 26 The Church is a living community made up of people of different opinions, attitudes, expectations, and behaviors, so they can interact with one another in some misunderstanding. Pragmatic-minded Pope Francis in relation to the service charisms holders for the good of the community, says: "Differences between persons and communities can sometimes prove uncomfortable, but the Holy Spirit, who is the source of that diversity, can bring forth something good from all things and turn it into an attractive means of evangelization. Diversity must always be reconciled by the help of the Holy Spirit; he alone can raise up diversity, plurality and multiplicity while at the same time bringing about unity."27 However, a great danger stems from conscious searching and enforcing differences; such action leads to the enforcement of its own decision and often leads to partitioning. The Apostolic exhortation Evangelii gaudium also points to the dangers of this kind: "When we, for our part, aspire to diversity, we become self-enclosed, exclusive and divisive; similarly, whenever we attempt to create unity on the basis of our human calculations, we end up imposing a monolithic uniformity. This is not helpful for the Church's mission.,"28

\footnotetext{
${ }^{23}$ Congregation for the Doctrine of the FAith, Iuvenescit Ecclesia, 2.

${ }^{24}$ Congregation for the Doctrine of the FAITH, Iuvenescit Ecclesia, 2.

${ }^{25}$ John PaUl II, Apostolic Exhortation Christifideles Laici, 24.

26 John PaUl II, "Interpretation of the Holy Witness 30 May 1998," cap. 6, p. 55.

27 The Holy Father Francis, Apostolic exhortation Evangelii gaudium, 131.

${ }^{28}$ The Holy FAther Francis, Apostolic exhortation Evangelii gaudium, 131.
} 


\section{CHARISMS AND PNEUMATOLOGICAL REALITY}

Every gift comes from the Father, through the Son, in the Holy Spirit. But the Holy Spirit is in the Church connected with the Son's mission, which is definitely fulfilled in the Easter mystery. Jesus Christ himself joins this fulfillment with the rebuke of the Holy Spirit to the community of believers. „But the Counselor, the Holy Spirit, whom the Father will send in my name, will teach you all things and remind you of everything I have told you" (Jn 14:26). The Congregation for the Doctrine of the Faith emphasizes: "Through this, the Holy Spirit can in no way inaugurate an economy other than that of the divine incarnate Logos, crucified and risen. In truth, the whole sacramental economy of the Church is the pneumatological realization of the Incarnation: the Holy Spirit, therefore, comes to be considered by Tradition as the soul of the Church which is the Body of Christ. The action of God in history always implies the relationship between the Son and the Holy Spirit, who, in Irenaeus of Lyon's evocative words, are called the two hands of the Father." 29 In this sense, every gift of the Spirit cannot but be in relationship with the Word made flesh." ${ }^{30}$ The document of Congregation for the Doctrine of the Faith Iuvenescit Ecclesia clearly expresses the interrelationships between hierarchical and charismatic gifts: "The bond in origin between the hierarchal gifts, conferred with the sacramental grace of Orders, and the charismatic gifts, freely distributed by the Holy Spirit, has its deepest roots, therefore, in the relationship between the divine incarnate Logos and the Holy Spirit, who is always the Spirit of the Father and of the Son. Precisely to avoid equivocal theological visions that would posit a «Church of the Spirit», distinct and separate from the hierarchical-institutional Church, it must be repeated that the two divine missions mutually imply each other in every gift bestowed freely upon the Church. In reality, the mission of Jesus Christ already implies within itself the action of the Spirit." ${ }^{31}$

\footnotetext{
29 "This comparison shows that St. Irene, on the one hand, distinguished between the mission of the Son of God and the Holy Ghost, but on the other hand he pointed to their joint commitment to the creation of the world." Jana MoRICOVÁ, "The Creation of the Most Holy Trinity according to St. Irene of Lyon," in: Anton ADAM, Jana MorICOVÁ (Eds.), Various Aspects of Theology of Creation. Proceedings of the Dogmatic Symposium (15.11.2001) (Badín, 2001), 78th.

${ }^{30}$ CONGRegation for the Doctrine of the FAITH, Iuvenescit Ecclesia, 11.

31 Congregation for the Doctrine of the FAith, Iuvenescit Ecclesia, 11.
} 


\section{CHARISMS AND THEIR AUTHENTICITY}

In the context of everything that has been said, the question is, how and to what extent should the charisms be examined, respectively, the holders of the charisms. It is necessary to keep in mind what the Church is stating in strict terms when it says that charisms given to individuals should serve the good of the whole Church community. It is also clear that the attitude of humility, simplicity, and openness is also expected in those who profess and represent themselves as bearers of gifts - charisms. Experience and practice show that this is not the case; not always charismatic - a person with charisma, is a man of open humility with whom he wants to serve in favor of the Church. In the initiatives of some Christian groups seem to place too much emphasis on keeping their own standards, customs or styles. The Holy Father Francis sees danger in it. In the exhortation Gaudete et exsultate says: "The Gospel then tends to be reduced and constricted, deprived of its simplicity, allure and savour. This may well be a subtle form of pelagianism, for it appears to subject the life of grace to certain human structures. It can affect groups, movements and communities, and it explains why so often they begin with an intense life in the Spirit, only to end up fossilized... or corrupt." 32 John Paul II highlights: "The charisms are received in gratitude both on the part of the one who receives them, and also on the part of the entire Church. They are in fact a singularly rich source of grace for the vitality of the apostolate and for the holiness of the whole Body of Christ, provided that they be gifts that come truly from the Spirit and are exercised in full conformity with the authentic promptings of the Spirit. In this sense the discernment of charisms is always necessary." 33 The attitude of the pope is pragmatic, based on real knowledge, and knows that not everything that tends to be presented as a divine thing is actually coming from God. In the exhortation of Christifideles laici John Paul II. says openly: "We know that God acts in all Christians, and we are aware of the benefits which flow from charisms both for individuals and for the whole Christian community. Nevertheless, at the same time we are also aware of the power of sin and how it can disturb and confuse the life of the faithful and of the community." 34 No charism does not dispense for the obligation to accept the pastoral office in

\footnotetext{
32 The Holy Father Francis, Apostolic exhortation Gaudete et exsultate, 58.

33 John PaUl II, Apostolic Exhortation Christifideles Laici, 24.

${ }^{34}$ John PaUl II, Apostolic Exhortation Christifideles Laici, 24.
} 
the Church and the necessity of subordinating the decision of the shepherds of the Church. The Second Vatican Council writes with great clarity: "For their pastors know how much the laity contribute to the welfare of the entire Church. They also know that they were not ordained by Christ to take upon themselves alone the entire salvific mission of the Church toward the world. On the contrary they understand that it is their noble duty to shepherd the faithful and to recognize their ministries and charisms, so that all according to their proper roles may cooperate in this common undertaking with one mind. For we must all practice the truth in love, and so grow up in all things in Him who is head, Christ." 35 The Apostle Paul encourages: "But speaking the truth in love, let us grow in every way into him who is the head Christ. From him the whole body, fitted and knit together by every supporting ligament, promotes the growth of the body for building up itself in love by the proper working of each individual part" (Eph 4:15-16).

Unification with Christ, to whom all believers are called, is a common charisma aiming for their goal to be "the universal apostolic goal of the Church." The Second Vatican Council in the Decree obout the Apostolate of laymen says: "Among these associations, those which promote and encourage closer unity between the concrete life of the members and their faith must be given primary consideration. Associations are not ends unto themselves; rather they should serve the mission of the Church to the world. Their apostolic dynamism depends on their conformity with the goals of the Church as well as on the Christian witness and evangelical spirit of every member and of the whole association." 36 The Council speaks of the need to create mutual unity not only in the level of religious life, but also acting in spirit and with the intentions of the Church. Every movement and community must acquire and fully accept this requirement, which completes the mutual unity of charismatic communities in the context of the hierarchical structure of the whole Church. Every movement and community must acquire and fully accept this requirement, which completes the mutual unity of charismatic communities in the context of the hierarchical structure of the whole Church. "In this perspective, groups of the faithful, ecclesial movements, and new communities propose renewed forms of following Christ in which the communio cum Deo and the communio fidelium are deepened. Thus the attractiveness of the encounter with the Lord Jesus and the beauty of Christian existence lived

\footnotetext{
35 Second Vatican Ecumenical Council, Dogmatic constitution Lumen Gentium, 30.

${ }^{36}$ Second Vatican Ecumenical Council, Decree Apostolicam actuositatem, 19.
} 
in its integrity is brought to new social contexts. A particular form of mission and witness is also expressed in such an entity, encouraging the growth of both a lively awareness of the individual's Christian vocation as well as stable paths of Christian formation and ways of evangelical perfection." ${ }^{37}$ In the various communities, the lives of believers in different living conditions (lay people, consecrated servants, consecrated persons) are being developed in accordance with charisms, which points to the diverse wealth of the communityof the Catholic Church. St. John Paul II addressed the representatives of the movements of the new communities. He recognized in them a "providential answer" ${ }^{38}$ arising from the Holy Spirit to the necessity of communicating in a persuasive manner the Gospel to the whole world with regard considering the grand processes of change in action at a global level, often marked by a strongly secularized culture. ${ }^{39}$ John Paul II also reminded the time of "ecclesial maturity" has come for all of these ecclesial groups, which means their insertion "in the local Churches and in the parishes always remaining in communion with the pastors and attentive to their directions."40

The Second Vatican Council represents the offices and charisms as the gifts of the Spirit for the construction of the Body of Christ and its missions of salvation in the world. The Holy Spirit brings the Church to holiness in all its members. The Constitution Lumen Gentium teaches: "The Spirit dwells in the Church and in the hearts of the faithful, as in a temple (cf. 1 Cor 3:16; 6:19). In them He prays on their behalf and bears witness to the fact that they are adopted sons (cf. Gal 4:6; Rom 8:15-16.26). The Church, which the Spirit guides in way of all truth (cf. Jn 16:13) and which He unified in communion and in works of ministry, He both equips and directs with hierarchical and charismatic gifts and adorns with His fruits" (cf. Eph 4:11-12; 1 Cor 12:4; Gal 5:22). ${ }^{41}$ The Pontiffic emphasized - both in the past and today - the need to preserve unity in obedience to the Church's priests. Otherwise, the community is not a co-creator of unity, but it becomes a destructive force within the Church and can then also cause the personal life

\footnotetext{
${ }^{37}$ Congregation for the Doctrine of the FAIth, Iuvenescit Ecclesia, 2.

38 John PaUl II, "Discourse to those belonging to Ecclesial Movements and to the New Communities on the Vigil of Pentecost (30 May 1998)," 7, in: Insegnamenti di Giovanni Paolo II, XXI(1998), 1: 1123.

39 CONGRegation for the Doctrine of the FAIth, Iuvenescit Ecclesia, 2.

40 John PaUl II, "Discourse to those belonging to Ecclesial Movements and to the New Communities on the Vigil of Pentecost," 1124.

${ }^{41}$ Second Vatican Ecumenical Council, Dogmatic constitution Lumen gentium, 4.
} 
of its members to collapse. The purpose of the document submitted by the Congregation for the Doctrine of the Faith is in the light of the relationship between the "hierarchical and charismatic gifts", to underline those theological and ecclesiological elements whose comprehension will encourage a fruitful and ordered participation of the new groups in the communion and the mission of the Church. ${ }^{42}$ Pope Benedict XVI. in the post-synodal apostolic exhortation of the Sacramentum Caritatis, states: "Synodal fathers emphasized the desirability of greater involvement of the communities of consecrated life, movements and associations that, in the power of their charisma, can bring new impetus to the Christian formation. Even in our times, the Holy Spirit will not be mired with the shedding of his gifts to support the apostolic mission to the Church, which has the task of spreading faith and bringing it up to full maturity." 43 Pope Francis emphasizes that charisms are to stand in the service of the communion of the gospel. This is an important ecclesial requirement that points to the inclusion of not only the individual member of the charisma, but also of the whole charismatic community, or the movement into the universal Church. In the apostolic exhortation of the Evangelii Gaudium, Pope Francis says: "The Holy Spirit also enriches the entire evangelizing Church with different charisms. These gifts are meant to renew and build up the Church. They are not an inheritance, safely secured and entrusted to a small group for safekeeping; rather they are gifts of the Spirit integrated into the body of the Church, drawn to the centre which is Christ and then channelled into an evangelizing impulse." 44 The Christocentrism of the charismatic community is a clear sign that charisms in its bearers stands in the service of the Church. Not the charisms itself decides to incorporate into the structures of the Church, but the way in which the profession of those who have received in the Holy Spirit special gifts for their own sanctification and consecration of their brothers and sisters in the ecclesial community. "A sure sign of the authenticity of a charism is its ecclesial character, its ability to be integrated harmoniously into the life of God's holy and faithful people for the good of all." 45 The Catechism of the Catholic Church in the Charisms adds: "Whether extraordinary or simple and humble, charisms are graces of the Holy Spirit which directly or indirectly benefit the Church,

\footnotetext{
42 Congregation for the Doctrine of the Faith, Iuvenescit Ecclesia, 3.

${ }^{43}$ Cf. BenEDIKT XVI, "Vigil of Pentecost - Celebration of First Vespers and encounter with Ecclesial Movements and New Communities" (3rd of June 2006), AAS 98(2006), 509.

${ }^{44}$ The Holy Father Francis, Apostolic exhortation Evangelii gaudium, 130.

45 The Holy Father Francis, Apostolic exhortation Evangelii gaudium, 130.
} 
ordered as they are to her building up, to the good of men, and to the needs of the world." 46 The Church Authority is aware that it is impossible to predict what charisms the Holy Spirit will raise and therefore must always be judged according to the rules of faith and in view of the growth of the Church. ${ }^{47}$ Pope John Paul II during the World Congress of Church Movements, highlighted the contribution of new lay communities inspired by the Gospel councils. He addresses the members of these communities: "You have learned in the movements and new communities that faith is not abstract talk, nor vague religious sentiment, but new life in Christ instilled by the Holy Spirit." 48 The importance of Charisma in the Church and their survival in the fullness of the mission they bring is indisputable. But the pope puts an urgent question of authenticity: "How is it possible to safeguard and guarantee a charism's authenticity?" And in the same speech continues: "It is essential in this regard that every movement submit to the discernment of the competent ecclesiastical authority." ${ }^{49}$ In other words, in the context, he quotes the Lumen gentium constitution, which we have already referred to above. On this place, we still recall the pope's request, which, even after many years, is equally urgent, because the importance of the proper guidance of charismatic gifts in their bearers to the community of the whole Church is important. John Paul II asks: "you always to adhere to them with generosity and humility, bringing your experiences to the local Churches and parishes ${ }^{50}$ while always remaining in communion with the Pastors and attentive to their direction." 51

We consider it indispensable that charisms should stand in the service of sanctification of the individual and have been beneficial to the community of

\footnotetext{
46 Catechism of the Catholic Church, 799.

${ }^{47}$ Cf. SACRed Congregation for Religious and for SeCular InSTITUtes. SACREd ConGREGATION FOR BISHOPS, Mutual relations, 51, AAS 70(1978), 499-500; JOHN PAUL II, Apostolic constitution Vita consecrata, 48, AAS 88(1996), 421-422; JOHN PAUL II, "General audience (24th of Jun 1992)", 6, in: Insegnamenti di Giovanni Paolo II, XV(1992), 1: 1935-1936.

${ }^{48}$ Pope John Paul II, "Prayer Vigil for the World Congress of Ecclesial Movements and New Communities (30th of May 1998)," in: Papal Leaves and Vatican Documents, vol. 14, World Congress of the Church Movements. Vatican 27.-29 May 1998 (Trnava: St. Vojtech's Association, 1998), cap. 7, p. 57.

${ }^{49}$ Pope John PaUl II, "Prayer Vigil for the World Congress of Ecclesial Movements and New Communities (30th of May 1998)," cap. 8, p. 57.

50 John Paul II, Apostolic Exhortation Christifideles Laici, 30.

${ }^{51}$ Pope John Paul II, "Prayer Vigil for the World Congress of Ecclesial Movements and New Communities (30th of May 1998)," cap. 8, p. 58.
} 
universal Church. In particular, we recommend the document Iuvenescit Ecclesia of The Congregation for the Doctrine of the Faith as a unique expert text in which the professional public finds a clearly formulated attitude to charisms as a gift, while at the same time fulfilling them in a particular relationship in the life of the Church. Present time requires a correct attitude not only to theological formula by charisms but by accepting a relationship that arises in the mutual context of charismatic and hierarchical gifts. The Holy Spirit of Sacrifice helps to know the truth of life in order to reach the Truth of Eternal Life.

\section{BIBLIOGRAPHY}

BENEDIKT XVI. Homília na prvé vešpery sviatku Turíc (3.júna 2006). AAS 98(2006), 509.

DRUHÝ VATIKÁNSKY KONCIL. "Dekrét Apostolicam actuositatem." In: Dokumenty Druhého vatikánskeho koncilu. Trnava: Spolok sv. Vojtecha, 2008.

DRUHÝ VATIKÁNSKY KONCIL. "Pastorálna konštitúcia Gaudium et spes." In: Dokumenty Druhého vatikánskeho koncilu. Trnava: Spolok sv. Vojtecha, 2008, 205-302.

DRUHÝ VATIKÁNSKY KONCIL. "Dekrét Unitatis redintegratio.” In: Dokumenty Druhého vatikánskeho koncilu. Trnava: Spolok sv. Vojtecha, 2008.

DRUHÝ VATIKÁNSKY KONCIL. "Vieroučná konštitúcia Lumen gentium." In: Dokumenty Druhého vatikánskeho koncilu. Trnava: Spolok sv. Vojtecha, 2008, 59-138.

FRANTIŠEK. Apoštolská exhortácia Evangelii gaudium. Dostupné na: https://www.kbs.sk/obsah /sekcia/h/dokumenty-a-vyhlasenia/p/dokumenty-papezov/c/apostolska-exhortacia-evangeliigaudium [cit. 7.11.2018].

FRANTIŠEK. Apoštolská exhortácia Gaudete et exsultate. Dostupné na: https://www.kbs.sk/ob $\mathrm{sah} /$ sekcia/h/dokumenty-a-vyhlasenia/p/dokumenty-papezov/c/apostolska-exhortacia-gaudeteet-exsultate [cit. 8.11.2018].

JÁN PAVOL II. Encyklika Dominum et Vivificantem.

JÁN PAVOL II. Apoštolská exhortácia Christifideles laici.

JÁN PAVOL II. "Príhovor na Svätodušnú vigíliu 30.mája 1998.” In: Pápežské listy a vatikánske dokumenty. Zv. 14. Svetový kongres cirkevných hnutí. Vatikán 27.-29.mája 1998. Trnava: Spolok sv. Vojtecha 1998.

JÁN PAVOL II. Apoštolská exhortácia Vita consecrata, 48. AAS 88(1996), 421-422.

JÁN PAVOL II. "Generálna audiencia (24. júna 1992)," 6. In: Insegnamenti di Giovanni Paolo II, XV(1992), 1: 1935-1936.

JÁn Zlatoústy. Homilia de Pentecoste, II, 1: PG 50, 464.

Katechizmus Katolíckej Cirkvi. Trnava: Spolok sv. Vojtecha, 1999.

Kongregácia Pre NÁUKu VIERY. Iuvenescit Ecclesia. Dostupné na: https://www.kbs.sk/obsah /sek cia/h/dokumenty-a-vyhlasenia/p/dokumenty-vatikanskych-uradov/c/iuvenescit-ecclesia [cit. 7.11.2018].

Kongregácia Pre Rehoľníkov a Sekulárne InŠtitúty - Kongregácia Pre Biskupov. Smernice Mutuae relationes, 51. AAS 70(1978), 499-500. 


\title{
CHARYZMATY W SŁUŻBIE KOŚCIOŁA POWSZECHNEGO
}

\author{
S t r e s z c z e n i e
}

Z eklezjologicznego punktu widzenia Kościół należy rozumieć jako dar Ojca i Ciało Mistyczne Chrystusa. Ciało Chrystusowe ożywiane jest Duchem Świętym, który obdarza Kościół posługiwaniami, urzędami i charyzmatami. Duch Święty prowadzi Kościół, mający udział w życiu Trójcy Przenajświętszej, do jego pełni. Równocześnie obdarza go szczególnymi impulsami i darami zwanymi charyzmatami. Dokument Kongregacji Nauki Wiary Iuvenescit Ecclesia wskazuje na wzajemne relacje między darami hierarchicznymi a charyzmatycznymi. Charyzmaty powinny służyć dobru Kościoła uniwersalnego. Każdy poszczególny chrześcijanin przyczynia się do budowania Kościoła poprzez swoje charyzmaty oraz swoją służbę. Żaden charyzmat nie udziala dyspensy od obowiązku akceptacji urzędu pasterskiego w Kościele oraz od konieczności podporządkowania się decyzjom pasterzy Kościoła. Jasnym znakiem autentyczności charyzmatu jest jego eklezjalność, jego zdolność do harmonijnego włączenia się w życie świętego Ludu Bożego dla dobra wszystkich.

Słowa kluczowe: Kościół; charyzmaty; Duch Święty; łaska; autentyczność. 